\title{
Hemoglobin Outcomes during Administration of Continuous Erythropoietin Receptor Activator (C.E.R.A): A Prospective, Observational, Multicenter Study
}

Dirk Henrich $^{1 *}$ and Michael Rambausek ${ }^{2}$

${ }^{1}$ Dialysis Center Saarlouis, Saarlouis, Germany

${ }^{2}$ Dialysis Center Mörikestrasse, Heilbronn, Germany

\begin{abstract}
Objective: To evaluate $\mathrm{Hb}$ outcomes in patients with dialysis-dependent or non-dialysis dependent chronic kidney disease (CKD) receiving continuous erythropoietin receptor activator (C.E.R.A.) therapy under routine conditions at specialist nephrology centers in Germany.

Methods: In a 12-month, prospective, observational, multicenter study, $\mathrm{Hb}$ outcomes were assessed in 1,580 patients with CKD (1,184 dialysis-dependent, 326 non-dialysis dependent) given once-monthly C.E.R.A. under routine conditions.

Results: Across the total study population, mean hemoglobin was in the range $11.4-11.6 \mathrm{~g} / \mathrm{dL}$ at all post-baseline visits. In the 962 patients on hemodialysis who were pretreated with ESA including C.E.R.A., mean (SD) hemoglobin was 11.4 (1.2) $\mathrm{g} / \mathrm{dL}$ at baseline and 11.5 (1.1) $\mathrm{g} / \mathrm{dL}$ at month 12; the mean (SD) number of C.E.R.A. dose changes was 3.0 (2.4). For the 227 non-dialysis dependent patients without prior ESA therapy, mean hemoglobin values were 10.6 (1.1) $\mathrm{g} / \mathrm{dL}$ at baseline and $11.6(1.3) \mathrm{g} / \mathrm{dL}$ at month 12, with a mean of 1.0 (1.4) dose changes. Presence of diabetic nephropathy showed no clinically relevant effect on hemoglobin response in either group. Overall, the proportion of patients with every hemoglobin measurement within narrow $(\leq 2 \mathrm{~g} / \mathrm{dL})$ pre-specified ranges was low $(<10 \%)$, but higher for the range $10.0-13.0 \mathrm{~g} / \mathrm{dL}(28.7 \%)$, reflecting the known fluctuation in hemoglobin values over time. Patients managed at large centers were more likely to have hemoglobin range in the range 10-13 g/dL throughout the 12-month study, suggesting closer anemia management. In total, five patients $(0.3 \%)$ discontinued C.E.R.A. due to adverse events.
\end{abstract}

Conclusion: Switching dialysis-dependent patients from more frequent ESA regimens to once-monthly C.E.R.A. therapy or initiating once-monthly C.E.R.A. de novo in predialysis CKD patients appears to be an effective therapeutic strategy regardless of diabetic status.

Keywords: C.E.R.A.; Dosing; Efficacy; ESA; Hemodialysis; Observational'

\section{Background}

Anemia is a frequent complication of chronic kidney disease (CKD), affecting over a quarter of those with mild disease (stages 1-2), over half with CKD stage 4 and three-quarters of patients on dialysis [1]. The primary etiology of anemia in CKD is erythropoietin deficiency ('renal anemia'), which intensifies as kidney dysfunction progresses [2], and is often compounded by functional iron deficiency [3]. In addition to the well-recognized and debilitating symptoms of anemia such as fatigue, anemia is associated with reduced quality of life [4], increased risk of progression to end-stage renal disease, cardiovascular events and death [5,6], particularly as the severity of anemia worsens [6]. Recognizing this, the Kidney Disease Improving Global Outcomes (KDIGO) initiative advises that hemogloblin $(\mathrm{Hb})$ level be monitored regularly in all patients with CKD [7]. Erythropoiesis-stimulating agent (ESA) therapy remains the mainstay of anemia therapy in patients with CKD. It is recommended that administration of ESAs should be based on individualized management, taking into account the clinical situation and specific risks in particular patients, and that in general ESAs not be used to maintain $\mathrm{Hb}$ level above $11.5 \mathrm{~g} / \mathrm{dL}$, with an upper threshold of $13 \mathrm{~g} / \mathrm{dL}$ in all cases [7].

Maintenance of $\mathrm{Hb}$ level will often require long-term administration of ESA therapy. Typically, epoetin alfa or epoetin beta are given twice or three times a week, and darbepoetin every 2-4 weeks during the maintenance phase. Longer dosing intervals would be time-saving for staff and convenient for patients, particularly not on dialysis, but the half-lives of these therapies are relatively short (up to 9 hours for epoetin alfa and beta [8] and approximately 25 hours for darbepoetin alfa [9]). Continuous erythropoietin receptor activator (C.E.R.A.) is a modified recombinant human erythropoietin which has a longer half-life (approximately 132 hours), a relatively low binding affinity for the erythropoiesis receptor and low systemic clearance in CKD patients [10]. Consequently, C.E.R.A. can be dosed every two weeks in dialysis-dependent patients and once a month in non-dialysis dependent CKD patients during the correction phase and monthly (intravenously or subcutaneously) in all patients during maintenance therapy [11]. Randomized trials have demonstrated the effectiveness of C.E.R.A. using different dosing regimens in dialysis dependent patients converted from other ESA therapies [12-16], and in ESAnaïve non-dialysis dependent patients [17-19]. In the absence of protocol-stipulated $\mathrm{Hb}$ monitoring and ESA dosing, however, anemia management and C.E.R.A. administration will vary between centers and results from controlled trials may not be replicated in routine practice.

*Corresponding author: Dirk Henrich, Dialysis Center Saarlouis, Vaubanstr 27 66740 Saarlouis, Saarland, Germany, Tel: +49 6831986 1777; E-mail: henrich@ dialyse-saarlouis.de

Received: August 19, 2015; Accepted: August 27, 2015; Published: September 04, 2015

Citation: Henrich D, Rambausek M (2015) Hemoglobin Outcomes during Administration of Continuous Erythropoietin Receptor Activator (C.E.R.A): A Prospective, Observational, Multicenter Study. J Nephrol Ther 5: 211. doi:10.4172/21610959.1000211

Copyright: $\odot 2015$ Henrich D, et al. This is an open-access article distributed under the terms of the Creative Commons Attribution License, which permits unrestricted use, distribution, and reproduction in any medium, provided the original author and source are credited. 
In particular, the use of C.E.R.A. in specific patient subpopulations, for example those with diabetes, and at specific types of centers, remain largely unexamined outside the confines of randomized studies.

Against this background, a prospective, observational study was undertaken to evaluate $\mathrm{Hb}$ outcomes in patients with dialysisdependent or non-dialysis dependent CKD receiving C.E.R.A. therapy under routine conditions at specialist nephrology centers in Germany.

\section{Methods}

\section{Study design and conduct}

This was a 12-month, prospective, observational study of adult patients with dialysis dependent or non-dialysis dependent CKD in whom the treating physician had decided to initiate C.E.R.A. therapy. C.E.R.A. dosing was at the discretion of the treating physician. The study was conducted at nephrology centers in Germany during December 2009 to February 2013. Written informed consent was obtained from all patients

\section{Patients}

It was planned to recruit between 1,500 and 2,250 patients aged $>18$ years in whom C.E.R.A. therapy had been initiated by their physician. Eligible patients were required to be free of malignancy and serious hematological or infectious disease, have a life expectancy of at least 12 months, be free of acute bleeding for the 16 weeks prior to enrollment, and not be taking part in an interventional trial. Female patients were not enrolled if they were pregnant or breast feeding. All patients recruited at a center were to be either receiving hemodialysis) or nondialysis dependent, to improve the homogeneity of data collection from each center.

\section{Data collection}

Data obtained at routine clinic visits were captured. Demographic information and clinical characteristics at baseline were recorded, with information on ESA medication in the 16 weeks prior to study entry and reason for initiation of C.E.R.A. therapy. At subsequent clinical visits, information was documented regarding C.E.R.A. dose, Hb level, other laboratory values including serum ferritin, transferrin saturation (TSAT) and C-reactive protein (CRP). Hb levels were obtained retrospectively for the 16 weeks prior to study entry, and prospectively during the 12-month evaluation period.

At the final visit of the 12-month study, the treating physician recorded whether the patient had discontinued the study, discontinued C.E.R.A. therapy, the reason for C.E.R.A. discontinuation if applicable, switch to another ESA therapy, and physician-reported and patientreported satisfaction with C.E.R.A. therapy ('very satisfied', 'satisfied', 'undecided' or 'not satisfied').

\section{Data analysis}

Patients were analyzed according to (i) whether they were receiving dialysis at study entry (CKD study 5 ) or were non-dialysis dependent $(\mathrm{CKD} \leq 4)$ (ii) receipt of ESA therapy (including C.E.R.A. therapy) in the 16 weeks prior to study entry (iii) whether the cause of CKD was diabetic nephropathy or not (iv) whether they received one or more C.E.R.A. dose modification or not and (v) according to the size of center. Study centers were categorized as large (treating $>100$ patients at the time of study initiation) or small ( $\leq 100$ patients).

Pre-defined efficacy variables included the proportions of patients with $\mathrm{Hb}$ response during months $0-12$ and months $6-12$; the maximum intra-individual fluctuation in $\mathrm{Hb}$ values from the individual mean during months $0-12$; changes in laboratory parameters over months $0-12$; the proportion of patients discontinuing the study or C.E.R.A. therapy; and physician and patient satisfaction with C.E.R.A. therapy. $\mathrm{Hb}$ response was defined as $\mathrm{Hb}$ within the following ranges at every study visit: $10.0-12.0 \mathrm{~g} / \mathrm{dL}, 11.0-12.0 \mathrm{~g} / \mathrm{dL}$ and 11.0-13.0 g/dL. Post $h o c$, a further $\mathrm{Hb}$ range (10-13 $\mathrm{g} / \mathrm{dL})$ was defined.

Although no formal sample size calculation was performed, it was planned to recruit a minimum of 50 patients per center, to achieve a representative sample of the local population of patients with CKD. Furthermore, it was planned that at least 30 centers should take part in the study to provide an adequate number of large and small centers for meaningful comparison, and to achieve a large population for analysis ( 1500 patients).

Data were summarized and presented descriptively. Efficacy data were analyzed for patients of the intent-to-treat (ITT) population, defined as all patients who received at least one dose of C.E.R.A. with at least one post-baseline efficacy assessment. Safety analyses were based on all patients who received at least one dose of C.E.R.A. and provided at least one safety assessment.

\section{Results}

\section{Study population}

In total, 1,580 patients were recruited at 33 centers. Of these, 33 patients were excluded from analyses since no baseline or subsequent information was provided $(\mathrm{n}=17)$ or because C.E.R.A. administration was not documented $(n=16)$. The safety population thus comprised 1,547 patients. A further 37 patients were excluded from the ITT population, most frequently due to no study visit (Figure 1), such that the ITT population included 1,510 patients. The study was discontinued prematurely by $469 / 1,510$ patients (31.1\%), with death due to underlying disease $(n=130)$ and discontinuation of treatment $(\mathrm{n}=114)$ the most common reasons (Figure 1).

In the ITT population, 1,184 patients $(78.4 \%)$ were receiving dialysis, of which the majority $(962 ; 81.3 \%)$ had received ESA therapy in the 16 weeks prior to study entry (Table 1). The remaining 326 patients $(21.6 \%)$ were non-dialysis dependent; 227 of these patients $(69.6 \%)$ had not received any ESA therapy in the preceding 16 weeks. The most frequent underlying cause of CKD was diabetic nephropathy in both the dialysis-dependent and non-dialysis dependent cohorts (Table 1). Concomitant conditions included heart failure (12.7\%), coronary artery disease $(30.3 \%)$, secondary hyperparathyroidism (30.6\%), type 1 diabetes (2.2\%), type 2 diabetes (39.9\%), dyslipidemia (14.8\%) and hypertension $(82.1 \%)$. The majority of patients $(56.2 \%)$ were managed at centers with 100 patients or fewer (Table 1).

Data on iron therapy were collected as part of standard capture of information about concomitant medication during the study. Administration of oral iron therapy was documented in 447 patients (29.6\%) and intravenous iron therapy in 697 patients (46.2\%), with a higher reported rate of iron therapy (of any type) in dialysis-dependent patients (84.2\%) than non-dialysis dependent patients (45.1\%). Intravenous preparations predominated in the dialysis dependent subgroup (695/1,184 [58.7\%] compared to 302/1,184 [25.5\%] for oral iron) and oral iron predominated in the non-dialysis dependent patients (145/326 [44.5\%] compared to $2 / 326$ [0.6\%] for intravenous iron). 
Citation: Henrich D, Rambausek M (2015) Hemoglobin Outcomes during Administration of Continuous Erythropoietin Receptor Activator (C.E.R.A): A Prospective, Observational, Multicenter Study. J Nephrol Ther 5: 211. doi:10.4172/2161-0959.1000211

Page 3 of 8

\section{C.E.R.A. therapy}

Among the patients who had receiving ESA therapy in the 16 weeks prior to study entry, the most frequent agent was C.E.R.A. (36.7\% of dialysis-dependent and $14.4 \%$ of non-dialysis dependent patients) (Table 2). Physicians reported the most frequent reason for initiation of C.E.R.A to be once-monthly administration (94.4\%) (Table 2). During the study, the median number of C.E.R.A. doses per month was 1.0 (interquartile range $1.0,1.0$ ) at each study visit to month 12. The mean (SD) dose increased slightly from baseline (109 [76] $\mu \mathrm{g}$ ) to the month 12 visit (121 [99] $\mu \mathrm{g})$, with a mean of 2.9 dose changes in the dialysis-dependent cohort compared to 1.0 dose changes in the non-dialysis dependent group (Table 2). In total, 490 patients (32.5\%) discontinued C.E.R.A. therapy (Figure 1). Among those who discontinued, 169 (34.5\%) switched to a different ESA therapy $(11.2 \%$ of the ITT population).

\section{Efficacy}

Across the total study population, mean $\mathrm{Hb}$ was in the range 11.4$11.6 \mathrm{~g} / \mathrm{dL}$ at all post-baseline visits (Figure 2). In the dialysis-dependent patients, mean (SD) Hb level was 11.3 (1.3) g/dL at study entry, and 11.6 (1.1) $\mathrm{g} / \mathrm{dL}$ at month 12; values in the subpopulation treated with ESA therapy before study entry were 11.491 .2$) \mathrm{g} / \mathrm{dL}$ and $11.5(1.1) \mathrm{g} / \mathrm{dL}$. Mean (SD) Hb level was lower in the non-dialysis dependent subgroup at baseline $(10.9[1.3] \mathrm{g} / \mathrm{dL})$ but identical to the dialysis-dependent cohort by month 12 (11.6 g/dL in both groups), an effect attributable to increase in $\mathrm{Hb}$ level after initiation of C.E.R.A. in the 227 ESA-naïve non-dialysis dependent patients (Table 3 ). This improvement accounted for the slight increase in mean $\mathrm{Hb}$ level in the total study population.

There was a significant inverse correlation between C.E.R.A. dose and $\mathrm{Hb}$ level in the study population overall $(\mathrm{r}=-0.319$ [Pearson coefficient]; $\mathrm{p}<0.001)$ in the study population overall. The correlation was $r=-0.366(p<0.001)$ for the subpopulation of dialysis-dependent patients previously treated with ESA therapy, and $r=-0.305(p<0.001)$ for the cohort of ESA-naïve non-dialysis dependent patients.

\section{$\mathrm{Hb}$ fluctuation and response rates}

Mean (SD) intra-individual $\mathrm{Hb}$ fluctuation from the individual mean during the 12-month study was $1.5(0.8) \mathrm{g} / \mathrm{dL}$ overall, with greater fluctuation in patients receiving dialysis (Table 3 ). The maximum intra-individual $\mathrm{Hb}$ fluctuation was $\leq 1 \mathrm{~g} / \mathrm{dL}$ in 393 patients $(26.0 \%)$ (259/1,184 dialysis-dependent patients [21.9\%]; 134/326 non-dialysis

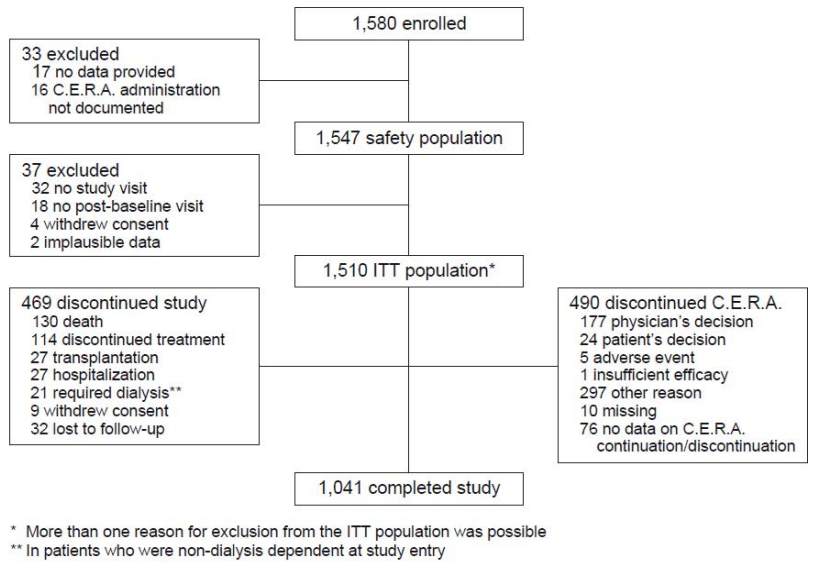

Figure 1: Patient disposition.

\begin{tabular}{|c|c|c|c|}
\hline & $\begin{array}{l}\text { Dialysis } \\
(N=1,184)\end{array}$ & $\begin{array}{l}\text { Non-dialysis } \\
\quad(\mathrm{N}=326)\end{array}$ & Total $(n=1,510)$ \\
\hline Age, years & $68.0(13.8)$ & $71.8(13.3)$ & $68.8(13.8)$ \\
\hline $\begin{array}{c}\text { Age }<65 \text { years } \\
n(\%)\end{array}$ & $402(34.0)$ & $70(21.5)$ & $472(31.3)$ \\
\hline Male gender, $\mathrm{n}(\%)$ & 705 (59.5) & $168(51.5)$ & $873(57.8)$ \\
\hline Weight (kg) & $77.1(16.5)$ & $79.7(17.0)$ & $77.7(16.6)$ \\
\hline $\begin{array}{l}\text { Body mass index } \\
\quad(\mathrm{kg} / \mathrm{m} 2)\end{array}$ & $27.0(5.3)$ & $28.0(5.6)$ & $27.2(5.4)$ \\
\hline \multicolumn{4}{|c|}{ Underlying disease, $n$ (\%) } \\
\hline $\begin{array}{c}\text { Diabetic } \\
\text { nephropathy }\end{array}$ & $377(31.8)$ & $101(31.0)$ & $478(31.7)$ \\
\hline $\begin{array}{c}\text { Hypertensive } \\
\text { nephrosclerosis }\end{array}$ & $244(20.6)$ & $128(39.3)$ & $372(24.6)$ \\
\hline Glomerulonephritis & $178(15.0)$ & $21(6.4)$ & $199(13.2)$ \\
\hline $\begin{array}{c}\text { Pyelonephritis/ } \\
\text { interstitial nephritis }\end{array}$ & $68(5.7)$ & $24(7.4)$ & $92(6.1)$ \\
\hline $\begin{array}{l}\text { Polycystic kidney } \\
\text { disease }\end{array}$ & $71(6.0)$ & $16(4.9)$ & $87(5.8)$ \\
\hline Other & $326(27.5)$ & $73(22.4)$ & $399(26.4)$ \\
\hline Missing & $2(0.2)$ & 0 & $2(0.1)$ \\
\hline \multicolumn{4}{|c|}{ ESA therapy in 16 weeks prior to study entry, $n(\%)^{a}$} \\
\hline Any & $962(81.3)$ & $99(30.4)$ & 1,061 (70.3) \\
\hline C.E.R.A. & $435(36.7)$ & $47(14.4)$ & $482(31.9)$ \\
\hline Darbepoetin alpha & $212(17.9)$ & $45(13.8)$ & $257(17.0)$ \\
\hline Epoetin beta & $229(19.3)$ & $6(1.8)$ & $235(15.6)$ \\
\hline Epoetin alpha & $131(11.1)$ & $0(-)$ & $131(8.7)$ \\
\hline Biosimilar & $107(9.0)$ & $1(0.3)$ & $108(7.2)$ \\
\hline \multicolumn{4}{|c|}{ Frequency of ESA therapy in 16 weeks prior to study entry, $n(\%)^{a}$} \\
\hline $\begin{array}{l}\text { More than once } \\
\text { a week }\end{array}$ & $443(37.4)$ & $0(-)$ & $443(29.3)$ \\
\hline Once a week & $343(29.0)$ & $14(4.3)$ & $357(23.6)$ \\
\hline $\begin{array}{l}\text { Once every two } \\
\text { weeks }\end{array}$ & $62(5.2)$ & $38(11.7)$ & $100(6.6)$ \\
\hline $\begin{array}{l}\text { Once every three } \\
\text { weeks }\end{array}$ & $11(0.9)$ & $4(1.2)$ & $15(1.0)$ \\
\hline $\begin{array}{l}\text { Once every four } \\
\text { weeks }\end{array}$ & $588(49.7)$ & $49(15.0)$ & $637(42.2)$ \\
\hline Other & $21(1.8)$ & $3(0.9)$ & $24(1.6)$ \\
\hline Missing & $1(0.1)$ & $0(-)$ & $1(0.1)$ \\
\hline \multicolumn{4}{|c|}{ Reason for C.E.R.A. initiation, $\mathbf{n}(\%)^{b}$} \\
\hline $\begin{array}{l}\text { Once-monthly } \\
\text { administration }\end{array}$ & $1141(96.4)$ & $285(87.4)$ & $1,426(94.4)$ \\
\hline Long shelf-life & $578(48.8)$ & $75(23.0)$ & $653(43.2)$ \\
\hline $\begin{array}{l}\text { Good control of } \mathrm{Hb} \\
\text { levels }\end{array}$ & $186(15.7)$ & $121(37.1)$ & $307(20.3)$ \\
\hline Other & $21(1.8)$ & $0(-)$ & $21(1.4)$ \\
\hline Missing & $1(0.1)$ & $0(-)$ & $1(0.1)$ \\
\hline $\begin{array}{l}\text { Large center, } \mathrm{n} \\
(\%), \mathrm{c}\end{array}$ & $563(47.6)$ & $99(30.4)$ & $662(43.8)$ \\
\hline $\begin{array}{l}\text { Small center, } \mathrm{n} \\
(\%), \mathrm{c}\end{array}$ & $621(52.4)$ & $227(69.6)$ & $848(56.2)$ \\
\hline
\end{tabular}

Continuous variables are shown as mean (SD). Study centers were categorized as large (treating $>100$ patients at the time of study initiation) or small ( $\leq 100$ patients). aMore than one ESA was possible ${ }^{\mathrm{b}}$ More than one response was possible C.E.R.A.: continuous erythropoietin receptor activator; ESA: erythropoiesis-stimulating agent Table 1: Baseline characteristics and previous ESA therapy.

dependent patients [41.1\%]).

The proportion of patients with every $\mathrm{Hb}$ measurement within the pre-specified windows of 10.0-12.0 g/dL, 11.0-12.0 g/dL and 11.0-13.0 $\mathrm{g} / \mathrm{dL}$ during months $0-12$ was low, although somewhat higher during only months 6-12 (Table 3 ), as would be expected following time for 
Citation: Henrich D, Rambausek M (2015) Hemoglobin Outcomes during Administration of Continuous Erythropoietin Receptor Activator (C.E.R.A): A Prospective, Observational, Multicenter Study. J Nephrol Ther 5: 211. doi:10.4172/2161-0959.1000211

Page 4 of 8

\begin{tabular}{|c|c|c|c|c|c|}
\hline & \multicolumn{2}{|c|}{ Dialysis $(\mathrm{N}=1,184)$} & \multicolumn{2}{|c|}{ Non-dialysis ( $\mathrm{N}=326$ ) } & \multirow{2}{*}{ Total $(n=1,510)$} \\
\hline & $\begin{array}{l}\text { All patients } \\
(n=1,184)\end{array}$ & $\begin{array}{l}\text { ESA prior to study entry } \\
\qquad(n=962)\end{array}$ & $\begin{array}{l}\text { All patients } \\
(n=326)\end{array}$ & $\begin{array}{l}\text { No ESA prior to study entry } \\
\qquad(n=227)\end{array}$ & \\
\hline \multicolumn{6}{|l|}{ Route of administration, $\mathbf{n}(\%)$} \\
\hline Intravenous & $1085(91.6)$ & $909(94.5)$ & $0(0)$ & $0(0)$ & $1085(71.9)$ \\
\hline Subcutaneous & $76(6.4)$ & $36(3.7)$ & $317(97.2)$ & $220(96.9)$ & $393(26.0)$ \\
\hline Both & $23(1.9)$ & $17(1.8)$ & $9(2.8)$ & $7(3.1)$ & $32(2.1)$ \\
\hline \multicolumn{6}{|l|}{ C.E.R.A. dose at baseline, $\mu \mathrm{g}$} \\
\hline Mean (SD) & $118(81)$ & $121(82)$ & $77(39)$ & $76(37)$ & $109(76)$ \\
\hline Median (range) & $100(30,360)$ & $100(30,360)$ & $75(30,200)$ & $75(30,200)$ & $100(30,360)$ \\
\hline \multicolumn{6}{|l|}{ C.E.R.A. dose at month $12, \mu \mathrm{g}$} \\
\hline Mean (SD) & $131(104)$ & $132(106)$ & $79(60)$ & $79(58)$ & $121(99)$ \\
\hline Median (range) & $100(30,1080)$ & $100(30,1080)$ & $68(30,400)$ & $75(30,400)$ & $100(30,1080)$ \\
\hline $\begin{array}{l}\geq 1 \text { C.E.R.A. dose change, } n \\
(\%)\end{array}$ & $942(79.6)$ & $780(81.1)$ & $169(51.8)$ & $118(52.0)$ & $1111(73.6)$ \\
\hline $\begin{array}{c}\text { No C.E.R.A. dose change, } \\
n(\%)\end{array}$ & $242(20.4)$ & $182(18.9)$ & $157(48.1)$ & $109(48.0)$ & $399(26.4)$ \\
\hline \multicolumn{6}{|l|}{ C.E.R.A. dose changes, $n$ (\%) } \\
\hline Mean (SD) & $2.9(2.4)$ & $3.0(2.4)$ & $1.0(1.3)$ & $1.0(1.4)$ & $2.5(2.4)$ \\
\hline Median (range) & $3(0,14)$ & $3.0(0,14)$ & $1(0,6)$ & $1.0(0,6)$ & $2(0,14)$ \\
\hline
\end{tabular}

${ }^{a}$ More than one response was possible ${ }^{b}$ More than one ESA was possibleC.E.R.A.: continuous erythropoietin receptor activator; SD: standard deviation

Table 2: C.E.R.A. therapy.

dose adjustments. Based on the wider $\mathrm{Hb}$ window of $10-13 \mathrm{~g} / \mathrm{dL}$, analyzed post hoc, $28.7 \%$ of patients remained within this window at all of the 12 study visits. Corresponding to the greater $\mathrm{Hb}$ fluctuation in dialysis patients, the proportion of patients within the predefined $\mathrm{Hb}$ windows was slightly higher in the non-dialysis dependent subpopulation (Table 3). Diabetic nephropathy did not adversely affect $\mathrm{Hb}$ levels or $\mathrm{Hb}$ response to C.E.R.A. in either the dialysis-dependent or non-dialysis dependent groups (Supplementary Table 1). Patients who required no C.E.R.A. dose modification exhibited slightly higher $\mathrm{Hb}$ response rates than those with one or more dose change during months $0-12$, as might be anticipated. Of interest, a higher proportion of patients managed at large centers remained within $10-13 \mathrm{~g} / \mathrm{dL}$ at all 12 study visits than those at small centers, particularly for non-dialysis dependent patients (Table 4). This may be related to the finding that C.E.R.A. dose was managed more closely at large centers: the mean (SD) number of dose changes was 3.0 (2.6) (median 3, range 0-14) versus $2.0(2.1)$ (median 1 , range $0-12$ ) at small centers.

\section{Laboratory values}

There was no consistent change in mean (SD) serum ferritin levels during the study from the month 1 visit onwards. The lowest value was observed at baseline (mean [SD] 403 [365] ng/mL), after which mean values remained in the range 413 to $567 \mathrm{ng} / \mathrm{mL}$. At month 12, mean (SD) serum ferritin was 479 (354) ng/mL. Similarly, the lowest TSAT level was at baseline (mean [SD] 24.4\% [11.8\%]), thereafter showing minor fluctuations within the range $25.7 \%$ to $28.2 \%$ with a mean (SD) level of $27.0 \%(11.8 \%)$ at month 12 . The lower end of the interquartile range for TSAT varied between $17.0 \%$ and $19.0 \%$ during the study. Mean CRP level showed no pattern of change during the study: mean (SD) values were 12.7 (27.1) nmol/L at baseline and 10.7 (22.2) nmol/L at month 12 , (median $4.7 \mathrm{nmol} / \mathrm{L}$ at both time points) with minor fluctuations at other time points.

\section{Physician and patient assessment}

At the final study visit, $45.4 \%, 39.9 \%, 9.0 \%$ and $2.1 \%$ of physicians were very satisfied, satisfied, undecided or dissatisfied with C.E.R.A. therapy. For patients, the corresponding proportions were $39.3 \%$, $47.2 \%, 7.5$ and $1.1 \%$. Data were missing in the remaining cases.

\section{Discussion}

During the 12-month course of this observational trial, oncemonthly treatment with C.E.R.A. maintained mean $\mathrm{Hb}$ level within the range 11.4-11.6 g/dL in a large cohort of patients with dialysis dependent or non-dialysis dependent CKD. Hb level remained unchanged under once-month C.E.R.A. in dialysis-dependent patients who had been receiving ESA therapy before study entry, approximately half of whom had previously been dosed at least every two weeks with non-C.E.R.A. preparations. In the $70 \%$ of non-dialysis dependent patients who were ESA-naïve at baseline, mean $\mathrm{Hb}$ showed an initial rise after C.E.R.A. initiation then remained stable to month 12 . The presence of diabetic nephropathy did not adversely affect the $\mathrm{Hb}$ response to C.E.R.A. Although patients who did not require any C.E.R.A. dose change were more likely to remain within target $\mathrm{Hb}$ range at all 12 study visits, patients managed at large centers - where dose changes were more frequent - were more likely to remain within target $\mathrm{Hb}$ ranges, suggesting closer anemia management.

The interval between C.E.R.A. doses was consistently one month throughout the 12-month study, with few exceptions. Dose changes were infrequent, with a mean of three dose changes over 12 months in the dialysis-dependent patients, in whom $\mathrm{Hb}$ fluctuation is known to be more marked, and a mean of only one dose change in the ESA-naive non-dialysis patients following the start of C.E.R.A. therapy. Over the 12-month study, patients with a dose modification were less likely to remain within specific $\mathrm{Hb}$ windows but after the first six months they 
(a)

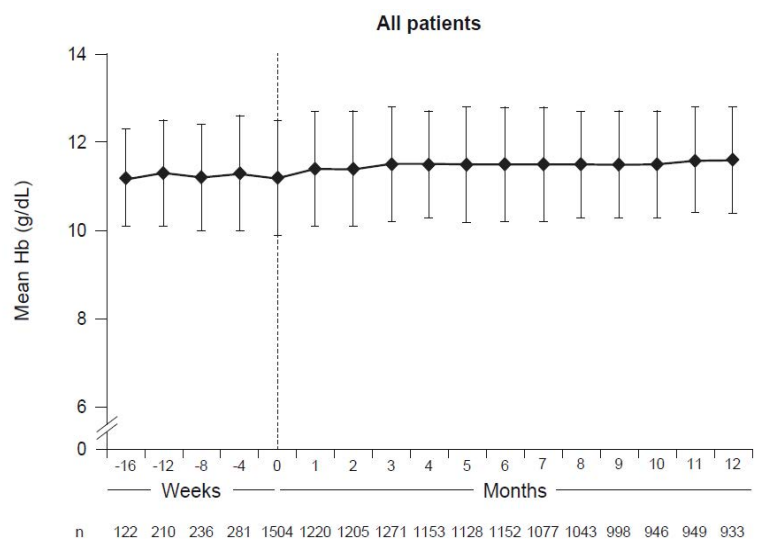

(b)

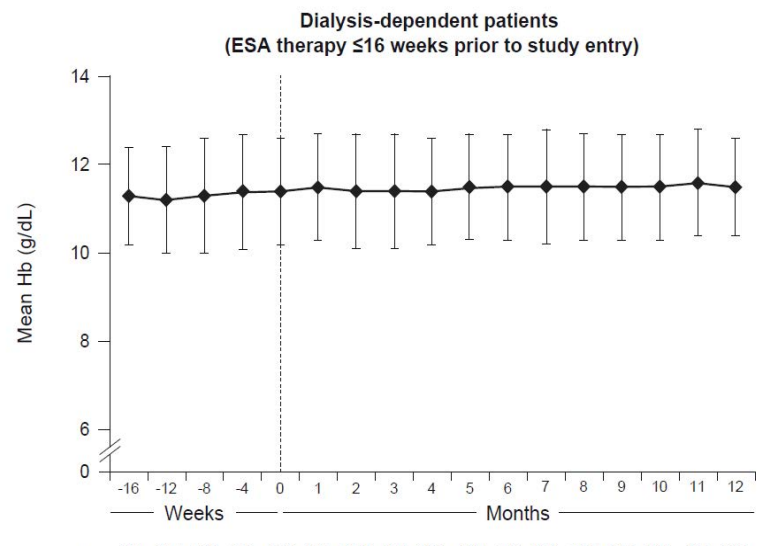

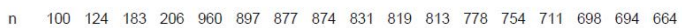

(c)

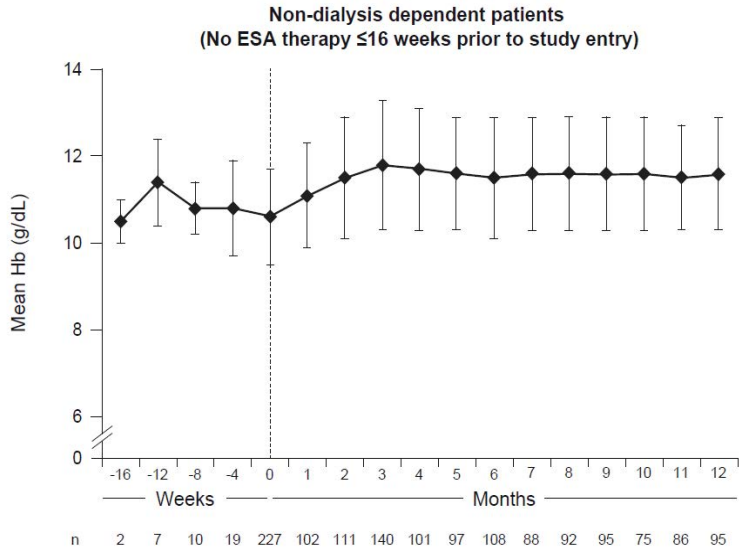

Figure 2: $\mathrm{Hb}$ level in the 16 weeks prior to study entry and during months $0-12$ (a) all patients (b) dialysis-dependent patients who received ESA therapy in the 16 weeks prior to study entry (c) non-dialysis dependent patients who did not receive ESA therapy prior to study entry. Values are shown as mean (SD).

were marginally more likely to do so, presumably because of the early dose adjustments. This is consistent with a previous observational study of 918 patients receiving C.E.R.A., in which patients receiving at least one dose change were more likely to remain within pre-specified ranges for $\mathrm{Hb}$ than those with no dose change [20].

Patients with CKD exhibit wide fluctuations in $\mathrm{Hb}$ levels [21,22] and it is notoriously difficult to sustain $\mathrm{Hb}$ levels within a specific target range consistently over an extended period during ESA therapy [23]. 
Citation: Henrich D, Rambausek M (2015) Hemoglobin Outcomes during Administration of Continuous Erythropoietin Receptor Activator (C.E.R.A): A Prospective, Observational, Multicenter Study. J Nephrol Ther 5: 211. doi:10.4172/2161-0959.1000211

Page 6 of 8

\begin{tabular}{|c|c|c|c|c|c|}
\hline & \multicolumn{2}{|c|}{ Dialysis } & \multicolumn{2}{|c|}{ Non-dialysis } & \multirow[b]{2}{*}{ Total } \\
\hline & All patients $(n=1,184)$ & $\begin{array}{l}\text { ESA prior to study entry } \\
\qquad(n=962)\end{array}$ & All patients $(n=326)$ & $\begin{array}{c}\text { No ESA prior to study entry } \\
(n=227)\end{array}$ & \\
\hline \multicolumn{6}{|l|}{ Hb, g/dL, mean (SD) } \\
\hline Baseline & $11.3(1.3)$ & $11.4(1.2)$ & $10.9(1.3)$ & $10.6(1.1)$ & $11.2(1.3)$ \\
\hline Month 12 & $11.6(1.1)$ & $11.5(1.1)$ & $11.6(1.2)$ & $11.6(1.3)$ & $11.6(1.1)$ \\
\hline Maximum $\mathrm{Hb}$ fluctuation, mean (SD) ${ }^{\mathrm{a}}$ & $1.6(0.8)$ & $1.6(0.8)$ & $1.3(0.8)$ & $1.4(0.8)$ & $1.5(0.8)$ \\
\hline \multicolumn{6}{|l|}{$\mathrm{Hb}$ response during months $0-12, n(\%)^{\mathrm{b}}$} \\
\hline $10.0-12.0 \mathrm{~g} / \mathrm{dL}$ & $67(5.7)$ & $50(5.2)$ & $29(8.9)$ & $18(7.9)$ & $96(6.4)$ \\
\hline $11.0-12.0 \mathrm{~g} / \mathrm{dL}$ & $3(0.3)$ & $2(0.2)$ & $2(0.6)$ & $1(0.4)$ & $5(0.3)$ \\
\hline $11.0-13.0 \mathrm{~g} / \mathrm{dL}$ & $76(6.4)$ & $61(6.3)$ & $33(10.1)$ & $18(7.9)$ & $109(7.2)$ \\
\hline $10.0-13.0 \mathrm{~g} / \mathrm{dL}$ & $322(27.2)$ & $266(27.7)$ & $112(34.4)$ & $70(30.8)$ & $434(28.7)$ \\
\hline \multicolumn{6}{|l|}{$\mathrm{Hb}$ response during months $6-12, n(\%)^{b}$} \\
\hline $10.0-12.0 \mathrm{~g} / \mathrm{dL}$ & $169(14.3)$ & $135(14.0)$ & $33(10.1)$ & $19(8.4)$ & $202(13.4)$ \\
\hline $11.0-12.0 \mathrm{~g} / \mathrm{dL}$ & $28(2.4)$ & $19(2.0)$ & $7(2.1)$ & $3(1.3)$ & $35(2.3)$ \\
\hline $11.0-13.0 \mathrm{~g} / \mathrm{dL}$ & $173(14.6)$ & $138(14.3)$ & $29(8.9)$ & $18(7.9)$ & $202(13.4)$ \\
\hline $10.0-13.0 \mathrm{~g} / \mathrm{dL}$ & $471(39.8)$ & $386(40.1)$ & $69(21.2)$ & $45(19.8)$ & $540(35.8)$ \\
\hline
\end{tabular}

aMaximum intra-individual fluctuation in $\mathrm{Hb}$ levels from mean during the 12-month study phase ${ }^{\mathrm{b}} \mathrm{Hb}$ response was defined as all $\mathrm{Hb}$ levels within the pre-specified window at every study visitHb: hemoglobin; SD: standard deviation

Table 3: Hb outcomes according to requirement for dialysis.

Naturally occurring $\mathrm{Hb}$ fluctuations caused by various factors such as concomitant illnesses, inflammation or iron therapy $[21,24,25]$ are exacerbated by intermittent bursts of erythropoietic activity stimulated by ESA administration. A one-year study of 68 ESA-treated patients receiving dialysis in the Netherlands revealed that no patient remained within the $\mathrm{Hb}$ target range of $11-12 \mathrm{~g} / \mathrm{dL}$ and that mean intra-individual $\mathrm{Hb}$ fluctuation was $>1.0 \mathrm{~g} / \mathrm{dL}$ [22], similar to our observations in the dialysis-dependent cohort. Their analysis also showed that fluctuation is greater during ESA therapy [22], as might be expected given the intermittent nature of ESA administration. Another observational study of 1,428 patients on hemodialysis found that only $4 \%$ of patients could be maintained within a $2 \mathrm{~g} / \mathrm{dL} \mathrm{Hb}$ window over 12 months [26], while a mean fluctuation $\geq 1.0 \mathrm{~g} / \mathrm{dL}$ was observed elsewhere in sis patients receiving epoetin or darbepoetin over a nine-month period [27]. Typically, hemodialysis patients exhibit a mean of $3.1 \mathrm{Hb}$ fluctuations each year, with a mean size of $2.5 \mathrm{~g} / \mathrm{dL}$ [28]. Non-dialysis CKD patients receiving ESA also show $\mathrm{Hb}$ variations but to a lesser extent than dialysis-treated individuals [22], consistent with our findings [22]. Against this background, considerable variation in $\mathrm{Hb}$ levels would be expected in the current study over a one-year period, especially since almost $80 \%$ of patients were on hemodialysis. Other studies of C.E.R.A. under routine conditions in various CKD settings have employed a three-month evaluation period [20,29-31]. Accordingly, the proportion of patients with every $\mathrm{Hb}$ level within prespecified windows was lower than reported elsewhere. For example, in other observational studies $\mathrm{Hb}$ was maintained within the narrow window of $11-12 \mathrm{~g} / \mathrm{dL}$ in $15-$ $20 \%$ of patients with hemodialysis dependent CKD [26], non-dialysis dependent CKD [29] or following kidney transplantation [31] over three-month evaluation periods, versus almost no patients here over a 12 -month period. For the wider window of $10-13 \mathrm{~g} / \mathrm{dL}, 65-75 \%$ of patients could be maintained in this range over a three-month period [26,32] but only $28.7 \%$ in the current 12 -month trial $(35.8 \%$ over months 6-12). Correspondingly, the mean intra-patient $\mathrm{Hb}$ variability in our population was $1.5 \mathrm{~g} / \mathrm{dL}$ compared to only $0.5 \mathrm{~g} / \mathrm{dL}$ over a period of three months in other publications [20,31]. In an observational study of 918 patients on hemodialysis, intra-patient $\mathrm{Hb}$ fluctuation increased to $1.4 \mathrm{~g} / \mathrm{dL}$ when monitored over nine months [20], close to that observed in our population. Drawing comparisons of $\mathrm{Hb}$ fluctuation, or the proportion of patients maintained within specific $\mathrm{Hb}$ windows, under the routine conditions of this study versus data from controlled trials of C.E.R.A. therapy is generally unhelpful since the exclusion criteria in interventional trials have typically excluded patients with $\mathrm{Hb}$ fluctuation $>1 \mathrm{~g} / \mathrm{dL}$ during a four-week screening period [12-15].

Dialysis patients were more likely to be receiving ESA at study entry than non-dialysis patients ( $81.3 \%$ versus $30.4 \%)$, and almost twice as likely to be receiving iron therapy, as would be anticipated given the greater loss of erythropoietin production and increasing frequency of anemia with worsening CKD [1]. Mean $\mathrm{Hb}$ was slightly higher than in non-dialysis dependent patients as a result. Nevertheless, $16.1 \%$ of hemodialysis patients had a $\mathrm{Hb}$ level $\leq 10 \mathrm{~g} / \mathrm{dL}$ at study entry. Of note, although mean TSAT was approximately $26-28 \%$ during the study, the lower limit of the interquartile threshold was $17-19 \%$, indicating the presence of functional iron deficiency in a sizeable number of patients.

Results from this study suggest that greater experience of managing C.E.R.A.-treated patients, as at the larger centers ( $\geq 100$ patients), may be associated with slightly closer control of $\mathrm{Hb}$ levels. While mean $\mathrm{Hb}$ levels were generally comparable between large and small centers at baseline and at the end of the study, slightly higher $\mathrm{Hb}$ response rates were observed at larger centers despite the fact that larger centers had a higher proportion of patients on hemodialysis, in whom close $\mathrm{Hb}$ control is challenging. This appears to contradict the fact that C.E.R.A. dose was adjusted more often in patients managed at larger centers than at smaller centers and that; overall, patients with dose changes were less likely to remain within $\mathrm{Hb}$ target windows. It is possible that C.E.R.A. dose changes were made more appropriately at the larger centers, possibly reacting sooner and in a more controlled manner than at less experienced smaller centers, but this remains speculative.

We recognize that the single-cohort design of this study prohibits 


\begin{tabular}{|c|c|c|}
\hline & Dialysis & Non-dialysis \\
\hline$\geq 1$ C.E.R.A dose change & $n=942$ & $n=169$ \\
\hline \multicolumn{3}{|l|}{$\mathrm{Hb}, \mathrm{g} / \mathrm{dL}$, mean (SD) } \\
\hline Baseline & $11.3(1.3)$ & $10.8(1.2)$ \\
\hline Month 12 & $11.5(1.1)$ & $11.4(1.2)$ \\
\hline $\begin{array}{l}\text { Maximum } \mathrm{Hb} \text { fluctuation, } \\
\text { mean (SD) }\end{array}$ & $1.7(0.8)$ & $1.4(0.8)$ \\
\hline \multicolumn{3}{|c|}{$\mathrm{Hb}$ response during months $6-12, n(\%)^{b}$} \\
\hline $10.0-12.0 \mathrm{~g} / \mathrm{dL}$ & $46(4.9)$ & $11(6.5)$ \\
\hline $11.0-12.0 \mathrm{~g} / \mathrm{dL}$ & $1(0.1)$ & $1(0.6)$ \\
\hline $11.0-13.0 \mathrm{~g} / \mathrm{dL}$ & $49(5.2)$ & $15(8.9)$ \\
\hline $10-13.0 \mathrm{~g} / \mathrm{dL}$ & $241(25.6)$ & $49(29.0)$ \\
\hline No C.E.R.A. dose change & $\mathrm{n}=\mathbf{2 4 2}$ & $n=157$ \\
\hline \multicolumn{3}{|l|}{ Hb, g/dL, mean (SD) } \\
\hline Baseline & $11.4(1.3)$ & $11.1(1.3)$ \\
\hline Month 12 & $12.0(1.1)$ & $12.1(1.2)$ \\
\hline $\begin{array}{l}\text { Maximum } \mathrm{Hb} \text { fluctuation, } \\
\text { mean }(\mathrm{SD})^{\mathrm{a}}\end{array}$ & $1.2(0.7)$ & $1.2(0.8)$ \\
\hline \multicolumn{3}{|c|}{$\mathrm{Hb}$ response during months $6-12, n(\%)^{b}$} \\
\hline $10.0-12.0 \mathrm{~g} / \mathrm{dL}$ & $21(8.7)$ & $18(11.5)$ \\
\hline $11.0-12.0 \mathrm{~g} / \mathrm{dL}$ & $2(0.8)$ & $1(0.6)$ \\
\hline $11.0-13.0 \mathrm{~g} / \mathrm{dL}$ & $27(11.2)$ & $18(11.5)$ \\
\hline $10-13.0 \mathrm{~g} / \mathrm{dL}$ & $81(33.5)$ & $63(40.1)$ \\
\hline Patients at large centers & $n=563$ & $n=99$ \\
\hline \multicolumn{3}{|l|}{ Hb, g/dL, mean (SD) } \\
\hline Baseline & $11.2(1.3)$ & $10.8(1.3)$ \\
\hline Month 12 & $11.5(1.1)$ & $11.3(1.2)$ \\
\hline $\begin{array}{l}\text { Maximum Hb fluctuation, } \\
\text { mean (SD) }\end{array}$ & $1.6(0.7)$ & $1.2(0.7)$ \\
\hline
\end{tabular}

$\mathrm{Hb}$ response during months $6-12, n(\%)^{b}$

\begin{tabular}{|c|c|c|}
\hline $10.0-12.0 \mathrm{~g} / \mathrm{dL}$ & $34(6.0)$ & $17(17.2)$ \\
\hline $11.0-12.0 \mathrm{~g} / \mathrm{dL}$ & $2(0.4)$ & $2(2.0)$ \\
\hline $11.0-13.0 \mathrm{~g} / \mathrm{dL}$ & $42(7.5)$ & $13(13.1)$ \\
\hline $10-13.0 \mathrm{~g} / \mathrm{dL}$ & $170(30.2)$ & $48(48.5)$ \\
\hline Patients at small centers & $n=621$ & $\mathrm{n}=227$ \\
\hline \multicolumn{3}{|l|}{$\mathrm{Hb}, \mathrm{g} / \mathrm{dL}$, mean (SD) } \\
\hline Baseline & $11.4(1.3)$ & $11.0(1.3)$ \\
\hline Month 12 & $11.6(1.2)$ & $11.8(1.3)$ \\
\hline $\begin{array}{l}\text { Maximum } \mathrm{Hb} \text { fluctuation, } \\
\text { mean }(\mathrm{SD})^{\mathrm{a}}\end{array}$ & $1.6(0.8)$ & $1.4(0.8)$ \\
\hline \multicolumn{3}{|c|}{$\mathrm{Hb}$ response during months $6-12, n(\%)^{b}$} \\
\hline $10.0-12.0 \mathrm{~g} / \mathrm{dL}$ & $33(5.3)$ & $12(5.3)$ \\
\hline $11.0-12.0 \mathrm{~g} / \mathrm{dL}$ & $1(0.2)$ & $0(0)$ \\
\hline $11.0-13.0 \mathrm{~g} / \mathrm{dL}$ & $34(5.5)$ & $20(8.8)$ \\
\hline $10-13.0 \mathrm{~g} / \mathrm{dL}$ & $152(24.5)$ & $64(28.2)$ \\
\hline
\end{tabular}

aMaximum intra-individual fluctuation in $\mathrm{Hb}$ levels from mean during the 12-month study phase. ${ }^{b} \mathrm{Hb}$ response was defined as all $\mathrm{Hb}$ levels within the pre-specified window at every study visit Study centers were categorized as large (treating $>100$ patients at the time of study initiation) or small ( $\leq 100$ patients).Values are shown as mean (SD)Hb: hemoglobin; SD: standard deviation

Table 4: $\mathrm{Hb}$ response according to C.E.R.A. dose modifications and study centre size.

efficacy comparisons with other treatment strategies, but a series of randomized trials has already shown that once-monthly dosing with C.E.R.A. achieves comparable $\mathrm{Hb}$ control to epoetin or darbepoetin [12-15]. The study was intended to evaluate once-monthly C.E.R.A. therapy based on local physician decision-making, in a typical population of dialysis-dependent or non-dialysis dependent CKD patients presenting to nephrology centers. As such, no control arm was included, few exclusion criteria were applied and both ESA-naïve and ESA-treated patients could be enrolled, to ensure wide applicability of findings. The large number of centers $(n=33)$, including both large and small units, also contributed to the generalizability of the results. Methodological challenges to achieving accurate and comprehensive capture of data regarding adverse events in this observational study across a large number of centers meant that the study did not attempt to assess adverse events during C.E.R.A. therapy, since the robustness of any conclusions could not be assured. The safety of C.E.R.A. has been described elsewhere [12-19,32].

This non-interventional study assessed outcomes using once-monthly C.E.R.A. therapy over a one-year period based on substantial numbers of patients at both large and small centers, thus closely reflecting practice. As such, the findings are applicable to routine practice in patients with dialysis dependent or non-dialysis dependent CKD. In this largely unselected population, it is clear that $\mathrm{Hb}$ fluctuation is considerable over a one-year period, and the results highlight the challenge of maintaining patients within narrow $\mathrm{Hb}$ target ranges. Slightly tighter $\mathrm{Hb}$ control was observed in patients treated at large nephrology centers, suggesting that greater experience improves anemia management with C.E.R.A., although specific reasons for this were not discernible in the current dataset. Overall, switching patients from more frequent ESA regimens to once-monthly C.E.R.A. therapy or initiating once-monthly C.E.R.A. de novo in CKD patients with or without hemodialysis appears to be an effective therapeutic strategy regardless of diabetic status.

\section{Disclosure}

The study was supported by Roche Pharma AG, Germany. A first draft of the manuscript was developed by a freelance medical writer with funding from Roche, based on the clinical study report. The draft was revised by the authors, who gave final approval for submission.

\section{Conflicts of interest}

M Rambausek has received speaker's honoraria and research funding from Roche. D Henrich has received a travel grant from Roche.

\section{Acknowledgements}

With grateful thanks to the study investigators and their teams. Matthias Anders, Leipzig; Jörg Baumann, Herford; Sabine Biernat, Varel; Alfred Bosch, Worms; Karl August Brensing, Bonn; Wilfried Dschietzig, Cottbus; Erika Eger Berlin; Ervé Garnier, Remscheid; Klaus Gondolf, Schwetzingen; Syrus Hafezi Mannheim; Steffen Hengst, Alsfeld Dirk Henrich, Saarlouis; Dorothee Hoffacker, Duisburg; Arnfried Klingbeil, Darmstadt; Manfred Küster, Varel; Frank Leistikow, Mannheim; Edgar Lensker, Nordhorn; Olaf Loke, Lüdenscheid; Manfred Lorenzen, Peine; Nexhat Miftari, Neckarsulm; Rainer Nowack, Lindau; Thomas Quaschning Villingen-Schwenningen; Michael Rambausek, Heilbronn; Hauke Salto, Peine; Uwe Schirrmeister, Bad Harzburg; Alexander Schischma, Schwabach; Michael Scholl, Mühlhausen; Volker Schumann, Herne; Wolfgang Seeger, Berlin; Dietmar Sehland Rostock; Efstratios Tatsis, Pinneberg; Edgar Frank Thiele, Georgsmarienhütte Ulrich Tholl, Kleve; Theoharis Tsobanelis, Frankfurt; Peter Weidemann, Aachen Stefan Zinn, Alsfeld.

The authors would like to thank $\operatorname{Pr}$ Nexhat Miftari for his substantial contributions to the study

\section{References}

1. McClellan W, Aronoff SL, Bolton WK, Hood S, Lorber DL, et al (2004) The prevalence of anemia in patients with chronic kidney disease. Curr Med Res Opin 20: 1501-1510.

2. Handelman GJ, Levin NW (2008) Iron and anemia in human biology: a review of mechanisms. Heart Fail Rev 13: 393-404.

3. Fishbane S (2007) Iron management in nondialysis-dependent CKD. Am J Kidney Dis 49: 736-743. 
Citation: Henrich D, Rambausek M (2015) Hemoglobin Outcomes during Administration of Continuous Erythropoietin Receptor Activator (C.E.R.A): A Prospective, Observational, Multicenter Study. J Nephrol Ther 5: 211. doi:10.4172/2161-0959.1000211

Page 8 of 8

4. Finkelstein FO, Story K, Firanek C, Mendelssohn D, Barre P, et al (2009) Health-related quality of life and hemoglobin levels in chronic kidney disease patients. Clin J Am Soc Nephrol 4: 33-38.

5. Fishbane $S$ (2008) Anemia and cardiovascular risk in the patient with kidney disease. Heart Fail Clin 4: 401-410.

6. Kovesdy CP, Trivedi BK, Kalantar-Zadeh K, Anderson JE (2006) Association of anemia with outcomes in men with moderate and severe chronic kidney disease. Kidney Int 69: 560-564.

7. Kidney Disease Improving Global Outcomes (KDIGO) (2012) Clinical Practice Guidelines for Anemia in Chronic Kidney Disease. Kidney Int Suppl 2: 279-335.

8. Halstenson CE, Macres M, Katz SA, Schnieders JR, Watanabe M, et al (1991) Comparative pharmacokinetics and pharmacodynamics of epoetin alfa and epoetin beta. Clin Pharmacol Ther 50: 702-712.

9. Macdougall IC, Gray SJ, Elston O, Breen C, Jenkins B, et al (1999) Pharmacokinetics of novel erythropoiesis stimulating protein compared with epoetin alfa in dialysis patients. J Am Soc Nephrol 10: 2392-2395

10. Macdougall IC, Robson R, Opatrna S, Liogier X, Pannier A, et al (2006) Pharmacokinetic and pharmacodynamics of intravenous and subcutaneous continuous erythropoietin receptor activator (C.E.R.A.) in patients with chronic kidney disease. Clin J Am Soc Nephrol 1: 1211-1215.

11. Locatelli F, Covic A, Eckardt KU, Wiecek A, Vanholder R (2009) Anaemia management in patients with chronic kidney disease: a position statement by the Anaemia Working Group of European Renal Best Practice (ERBP). Nephrol Dial Transplant 24: 348-354.

12. Canaud B, Mingardi G, Braun J, Aljama P, Kerr PG, et al; STRIATA Study Investigators (2008) Intravenous C.E.R.A. maintains stable haemoglobin levels in patients on dialysis previously treated with darbepoetin alfa: results from STRIATA, a randomized phase III study. Nephrol Dial Transplant 23: $3654-$ 3661.

13. Levin NW, Fishbane S, Cañedo FV, Zeig S, Nassar GM, et al; MAXIMA Study Investigators (2007) Intravenous methoxy polyethylene glycol-epoetin beta for haemoglobin control in patients with chronic kidney disease who are on dialysis: a randomized non-inferiority trial (MAXIMA). Lancet 370:1415-1421.

14. Sulowicz W, Locatelli F, Ryckelynck JP, Balla J, Csiky B, et al (2007) Oncemonthly subcutaneous C.E.R.A. maintains stable hemoglobin control in patients with chronic kidney disease on dialysis converted directly from epoetin one to three times weekly. Clin J Am Soc Nephrol 2: 637-646.

15. Spinowitz B, Coyne DW, Lok CE, Fraticelli M, Azer M, et al (2008) C.E.R.A maintains stable control of hemoglobin in patients with chronic kidney disease on dialysis when administered once every two weeks. Am J Nephrol 28: 280289.

16. Locatelli F, Villa G, de Francisco AL, Albertazzi A, Adrogue HJ, et al (2007) Effect of a continuous erythropoietin receptor activator (C.E.R.A.) on stable haemoglobin in patients with CKD on dialysis: once monthly administration. Curr Med Res Opin 23: 969-979.

17. Roger SD, Locatelli F, Woitas RP, Laville M, Tobe SW, et al (2011) C.E.R.A once every 4 weeks corrects anaemia and maintains haemoglobin in patients with chronic kidney disease not on dialysis. Nephrol Dial Transplant 26: $3980-$ 3986 .
18. Macdougall IC, Walker R, Provenzano R, de Alvaro F, Locay HR, et al (2008) C.E.R.A. corrects anemia in patients with chronic kidney disease not on dialysis: results of a randomized clinical trial. Clin J Am Soc Nephrol 3: 337-347.

19. Provenzano R, Besarab A, Macdougall IC, Ellison DH, Maxwell AP, et al (2007) The continuous erythropoietin receptor activator (C.E.R.A.) corrects anemia at extended administration intervals in patients with chronic kidney disease not on dialysis: results of a phase II study. Clin Nephrol 67: 306-317.

20. Weinreich T, Leistikow F, Hartmann HG, Vollgraf G, Dellanna F (2012) Monthly continuous erythropoietin receptor activator treatment maintains stable hemoglobin levels in routine clinical management of hemodialysis patients. Hemodial Int 16: 11-19.

21. Fishbane S, Berns JS (2005) Hemoglobin cycling in hemodialysis patients treated with recombinant human erythropoietin. Kidney Int; 68: 1337-1343.

22. van der Putten K, van der Baan FH, Schellekens H, Gaillard CA (2009) Hemoglobin variability in patients with chronic kidney disease in the Netherlands. Int J Artif Organs 32: 787-793.

23. Berns JS, Elzein H, Lynn RI, Fishbane S, Meisels IS, et al (2003) Hemoglobin variability in epoetin-treated hemodialysis patients. Kidney Int 64: 1514-1521.

24. Macdougall IC (2001) Individualizing target haemoglobin concentrationstailoring treatment for renal anaemia. Nephrol Dial Transplant 16: 9-14.

25. Richardson D (2002) Clinical factors influencing sensitivity and response to epoetin. Nephrol Dial 17: 53-59.

26. Portolés J, López-Gómez JM, Aljama $\mathrm{P}$ (2007) A prospective multicenter study of the role of anaemia as a risk factor in haemodialysis patients: the MAR Study. Nephrol Dial Transplant 22: 500-507.

27. Agrawal V, Mukherjee S, Kosuri R, Dumler F (2010) Anemia management with darbepoetin-alfa in outpatient hemodialysis patients switched from epoetinalfa. A community hospital experience. Am J Ther 17: 469-475.

28. Ebben JP, Gilbertson DT, Roley RN, Collins AJ (2006) Hemoglobin level variability: associations with comorbidity, intercurrent events, and hospitalizations. Clin J Am Soc Nephrol 1: 1205-1210.

29. Heidenreich S, Leistikow F, Zinn S, Baumann J, Atzeni A, et al (2012) Monthly administration of a continuous erythropoietin receptor activator provides efficient haemoglobin control in non-dialysis patients during routine clinical practice: results from the non-interventional, single-cohort, multicentre, SUPRA study. Clin Drug Investig 32: 99-110.

30. Fliser D, Kleophas W, Dellanna F, Winkler RE, Backs W, et al (2010) Evaluation of maintenance of stable haemoglobin levels in haemodialysis patients converting from epoetin or darbepoetin to monthly intravenous C.E.R.A.: the MIRACEL study. Curr Med Res Opin 26: 1083-1089.

31. Budde K, Rath T, Kliem V (2014) Anemia control in kidney transplant recipients using once-monthly continuous erythropoietin receptor activator: a prospective, observational study. J Transplant 2014: 179705.

32. Locatelli F, Mann JF, Aldigier JC, Sanz Guajardo D, Schmidt R, et al (2010) C.E.R.A. safety profile: a pooled analysis in patients with chronic kidney disease. Clin Nephrol 73: 94-103. 